\title{
COUNTERPART FUNDS AND DEVELOPMENT
}

\section{Simon Maxwell}

\section{INTRODUCTION}

The theory and practice of counterpart funds sounds like a dry and technical subject. It is. But new readers should not despair. As the authoritative articles in this issue of the Bulletin amply demonstrate, the topic of counterpart funds repays further study. Counterpart funds themselves play an important, growing and often controversial role in developing countries. More to the point, the topic is replete with linkages to broader issues in development: poverty targeting, aid conditionality, the management of the budgetary process - and many others.

To set the scene: 'counterpart funds' are 'local currency generated by the sale of foreign exchange or commodity aid, over the use of which the donor retains some control' (Bruton and Hill 1991 and in Section 3 of this Bulletin). They typically arise from programme aid, where foreign exchange is sold to importers; from food aid, where commodities are sold to mills or processing plants; and, more rarely, from sales of other commodities, such as fertilizer. Not all such transactions generate counterpart funds, since not all donors try to 'retain control' over local currency generated by their aid. Nevertheless, many donors do insist on setting up a fund which gives them some control over how local currency is spent.

Unfortunately, there is no international data series on counterpart funds. The figures cited by Fell in his article here imply that between 3 per cent and 12 per cent of all aid by DAC members may generate counterpart funds, but for some donors and many recipients, the figure is higher: between 10 per cent and 15 per cent for the European Community (Maxwell 1991, quoted by Tincani in this Bulletin), up to 20 per cent in the Sahel (Club du Sahel et al 1991, quoted by Fell) and potentially as high as 60 per cent in Mozambique (Riley in this volume). These are not high figures by historical standards: more than 40 per cent of Marshall Aid to Europe after World War II consisted of food, feed and fertilizer, most of which generated counterpart funds (Singer et al 1987).

Of course, aid plays a relatively small part in the economies of many countries, so that counterpart funds do not always make a large contribution to the government budget or the money supply (Bruton and Hill 1991 and in Section 2). There are exceptions, however, especially where counterpart funds have been allowed to accumulate as unexpended balances. A much-quoted case is Mozambique, where counterpart funds in 1990 supplied 30 per cent of the government budget (Riley in this volume). Another is Bangladesh, where counterpart funds in the 1970s accounted for 40 per cent of the government budget (Maxwell and Singer 1979). In 1990, unexpended balances were equivalent to 50 per cent of the money supply in Madagascar and 91 per cent in Guinea-Bissau (Tincani in this volume).

Counterpart funds are probably disproportionately important in sub-Saharan Africa (SSA), mainly because aid itself is disproportionately important: equivalent to over 8 per cent of GNP in 1987-89, compared to under 2 per cent in South Asia and under 0.5 per cent in Latin America (World Bank, World Development Report, various years). In addition, weak budgetary systems in many African countries mean that donors are more likely to insist on retaining some control over the use of local currency generated by aid.

Whether counterpart funds grow in the future will depend on the net outcome of two conflicting tendencies. On the one hand, the share of programme aid in total aid seems likely to rise, given the need to disburse funds quickly to poor countries and the pressure to monetise an increasing share of food aid (World Bank/WFP 1991 and Schulthes in this volume). This is likely to boost the flow of counterpart funds. On the other hand, the share of programme aid which generates counterpart funds seems likely to fall slowly, as some donors (but not all, as the articles in Section 4 indicate) become more relaxed about the earmarking of local currency. This is likely to reduce the flow of counterpart funds. The most probable outcome for the rest of the decade is that counterpart fund generation and use will increase in many poor countries, especially in SSA.

\section{ISSUES IN THE THEORY AND PRACTICE OF COUNTERPART FUNDS}

There has been a regular ebb and flow in discussion of counterpart funds since the early debate about Marshall Aid (e.g. McLeod 1950). There was a peak in the literature in the early 1960s, stimulated by controversy over the accumulation of US food aid counterpart funds in India, but then a lull (Maxwell and Singer 1979). This was broken as programme aid expanded in the 1980s and as attention shifted to SSA 
(Roemer 1989, Clément 1989, Bruton and Hill 1991). The debate over the monetisation of food aid also revived interest in the generation, management and targeting of food aid counterpart funds (WFP 1987a; 1987b; World Bank/WFP ibid). Owens (1991) has assembled an annotated bibliography of over 100 contributions to different aspects of the topic.

As a result of all this attention, the basic macroeconomics of counterpart funds are well understood. The first round effects are set out here in careful papers by Bruton and Hill (in Section 2) and by Clément. The second and subsequent round effects are explored by Maxwell and Green. Counterpart funds do not represent a new resource, over and above the original aid transfer, but they can have substantial effects on the money supply, the balance of payments, the composition of demand and the government budget.

In the simplest (first round) case, the sale of foreign exchange or commodities removes purchasing power from the economy and is deflationary; by contrast, the expenditure of counterpart funds increases the demand for goods and services and is reflationary. If these two events happen simultaneously, their effects cancel out. If, however, there is a long lag before the counterpart fund is spent, and especially if monetary compensation takes place in the meantime to counteract the original leakage, the effect of the counterpart fund expenditure may be inflationary. In the second and subsequent rounds of expenditure, consumption multipliers and production linkages arising from counterpart fund expenditure generate varying patterns of demand for different products, so that there are consequences for distribution between sectors; and, at the same time, additional demand for imports is generated, some of which will be for consumer goods. There are many variations to this story, which the articles explore. In particular, counterpart funds may be sterilized and used to pay back government debt, in which case the effects on the real economy are muted.

Within this framework, attention has focused on three main issues, each of which has linkages to wider development debates; first, how to improve the poverty targeting of programme aid; second, whether counterpart funds are needed or not, which links to the general question of aid conditionality; and third, how to improve the management of counterpart funds, which sheds light on the budgetary process. In addition to these major topics, other themes discussed in the papers include absorptive capacity, fiscal dependence and the inter-annual calibration of counterpart funds (see especially the papers by Maxwell and Green): these too raise questions of broader interest.

\section{a Poverty targeting through programme aid}

Poverty reduction has again (and at last) risen to the top of the international agenda (World Bank 1990; 1991; UN 1991). There are two main debates about the contribution counterpart funds might make. The first concerns programme aid provided in the form of general or sectoral import support programmes. These of ten have Balance of Payments support as the primary objective. If more specific developmental or poverty reduction objectives appear at all, they are usually found only in second place. The question is whether the counterpart fund mechanism can offer a way of overcoming this disadvantage and establishing a more direct link between Balance of Payments support and poverty reduction. The second debate is related but applies more specifically to food aid. It is about whether food aid commodities are best delivered in kind, or whether it is more appropriate to sell ('monetise') the commodities on the market, pay the proceeds into a counterpart fund and use these resources to help meet poverty reduction or food security objectives.

To take food aid first, monetisation has generated considerable controversy: some believe that only project food aid delivered in kind can be targeted effectively on the poor; others see equal scope in counterpart fund arrangements (World Bank/WFP 1991:23ff). The debate is reviewed here by Schulthes, who identifies three major constraints to increased monetisation: bureaucratic inertia in food aid agencies; absorptive capacity in recipient countries; and the nature of food aid distributed in kind, which, he suggests, is effectively self-targeting on the poor.

However, Schulthes goes on to argue that the constraints must be overcome if food aid is to make a larger contribution to poverty reduction. He presents a checklist of conditions under which monetisation may be the preferred option for targeted food aid programmes (see also Maxwell and Owens 1991:21) and suggests that monetised project food aid 'may lead the way to greater effectiveness of programme food aid'. Monetisation is appropriate wherever targeting can successfully and cost-effectively be achieved with cash without destabilizing local food markets.

Sculthes argues that the choice between direct distribution and monetisation should become a routine element of project design. Reporting on a workshop held at the IDS in January 1991, Maxwell and Owens go further: they conclude that there should be a presumption in favour of monetisation and conclude that 'direct distribution should only be considered where monetisation seems to be infeasible - because of difficulties of targeting, market failure or administrative barriers (Maxwell and Owens 1991:17)'.

Other articles tackle the more general debate and show how counterpart funds can be used to translate programme aid into domestic poverty-reduction 
programmes. The Social Funds cited by Gardiner are good examples. In Peru, Canadian counterpart funds were channelled to an independent organization with administrative and operational autonomy, which specialized in the informal sector, small business development and the health and welfare sectors. In Bolivia, a 'public by-pass agency' was established, with multi-donor support, to fund social and economic infrastructure: in 1989 the Fondo Social de Emergencia was responsible for about 80 per cent of all public investment in health and about 75 per cent in education.

Other donors have followed a similar route. In an interesting institutional development, USAID has used local currency from economic support programmes and food aid to establish endowments benefiting nonprofit private foundations in the fields of agricultural research, natural resource management or training (USAID 1990). 'Debt for environment' and 'debt for development' swaps also offer a close analogy to counterpart funds: here without a new inflow of commodities or cash, although there may be savings on foreign exchange for debt servicing (Griffiths-Jones 1992).

All these examples show that improved poverty targeting of programme aid is closely bound up with the generation and management of counterpart funds. Indeed, counterpart funds may provide a way of resolving a common dilemma of aid, which is how to disburse aid more rapidly without sacrificing a poverty focus (Healey and Winpenny 1991).

\section{b Conditionality and counterpart funds}

A purist might object to the discussion so far on the grounds that counterpart funds are merely an inefficient way of securing greater conditionality over government policy and the size and composition of the government budget. It is well known that counterpart funds themselves are not an additional resource, over and above the aid which generates them (Singer 1964). In that case, counterpart funds might be viewed as an unnecessary distraction from the core task of policy dialogue on the fiscal and monetary aggregates.

The purist position on counterpart funds is stated most clearly here by Clément, who argues for a 'clean' budgetary process in which counterpart funds are 'untied', effectively abolished, and merged into the government budget. This would avoid possible conflicts between individual donor priorities for spending accounts they control and the fiscal or credit targets agreed by the recipient country with the IMF and the World Bank. It would, as Green suggests, replace complex and disparate counterpart fund negotiations with 'an overall dialogue on resource use, with the proceeds of monetised commodity assistance flowing directly into general revenue'. There would be no problems with the fungibility of government expenditure, no headaches with administration, no risk of undermining shaky budgetary procedures in the recipient country and no risk that the accumulation of counterpart funds would create economic and political problems in the future.

Most economists might be expected to follow this line and it is indeed seen by many of the contributors as an ideal to be pursued. A surprising number, however, see virtue in counterpart funds, not only for donors but also for recipients, and especially in a second best world characterized by weak budgetary processes and, often, poor policy. Among the advantages claimed and examples cited are preserving social expenditures that governments are unable or unwilling to fund directly (Green, Tincani, Schulthes), the ability to channel resources to the voluntary sector (Gardiner) or the private sector (Bruton and Hill in Section 3) and, in general, guaranteeing minimum developmental effectiveness in countries with poor budgetary procedures (McClelland). Counterpart funds may be a clumsy device, but, as Bruton and Hill conclude, their 'flexibility and peculiarities' can be harnessed to 'accomplish things that otherwise could not be accomplished'. There are many examples in the papers, from the privatisation of public sector companies in Costa Rica (Bruton and Hill in Section 3), through the creation of social funds in Bolivia and Peru (Gardiner), to proposals for the creation of a famine fund in Ethiopia (Belshaw).

\section{c The management of counterpart funds}

Whatever the theoretical case for counterpart funds, the articles contain a litany of complaints about practical management: the failure to credit sales proceeds; the use of counterpart funds, resulting in unwanted and potentially destabilizing accumulation; very poor accounting and reporting; and, from the recipient point of view, bewilderment in the face of complex, time-consuming and diverse donor accounting requirements. The cases cited here provide illustrations of the weakness of the budgetary process in many developing countries.

Some of the most difficult problems arise in valuing commodities and ensuring that the full value is transferred to the counterpart fund. In many cases, commodities are undervalued, at a price which does not reflect the full import cost; in others, large deductions are made for administrative purposes; in still others, the recipient simply does not credit the account. Mozambique has been a particularly acute case (Riley). More generally, the European Community has estimated that a full 25 per cent of the counterpart value from its import support and food aid disappears as 'leakage' before the fund is credited (Knop 1989, 
quoted by Tincani).

A related problem is poor reporting and accounting. The difficulty facing recipient countries can be seen from the fact that Mozambique has substantial counterpart fund programmes with as many as ten different donors, all requiring different procedures (Riley). However, attempts to introduce 'common', multi-donor counterpart funds have made little progress, in Mozambique or elsewhere (Riley, Schulthes).

Finally, the question of what to do about 'overhangs' of unspent balances has been a recurrent concern since the Indian experience of the 1960s. When accumulations take place, there have almost always been compensations in monetary policy at an earlier stage, so that spending the fund would be inflationary, Furthermore, the size of the fund makes control a political issue between donor and recipient. The solution agreed between India and the US in the 1960s was to write-off the overhang. In the 1980 s and 1990 s, sterilization or use to pay off (internal) government debt has been an increasingly common use (Bruton and Hill in Section 3).

\section{THE POLICY FRAMEWORK FOR COUNTERPART FUNDS}

The new wave of interest in counterpart funds has produced new policy guidelines. In 1991 an international workshop at the IDS agreed a statement of guiding principles (Figure 1); the group of donors working together in the Special Programme of Assistance to SSA adopted guidelines on counterpart funds (appended to the paper by Tincani); the Development Assistance Committee of the OECD adopted new Principles for Programme Assistance, which include treatment of counterpart funds (appended to the article by Fell); the European Community adopted a Resolution on counterpart funds (discussed by Tincani); and USAID issued new policy guidelines on the subject (described and discussed by $\mathrm{McClelland).} \mathrm{In} \mathrm{addition,} \mathrm{there} \mathrm{has} \mathrm{been}$ progress on the question of food aid monetisation: the checklist originally presented to the Sussex workshop by Schulthes and reproduced in modified form in his article; and new guidelines on monetisation of project food aid issued by USAID (1991).
There is broad agreement in all these policy statements about the role of counterpart funds. Figure 1 summarizes the consensus. Counterpart funds are not an additional resource, but they do constitute a mechanism for supporting the government budget. The key first step is for donors and recipients to agree on the strategic objectives of policy and on the policies, programmes and projects required. There may or may not then be a need for counterpart funds. If there is a need, they should be planned in advance, credited without delay at the full import value and disbursed quickly on agreed objectives, including debt reduction where appropriate. They should be managed in such a way as to minimize the administrative load on recipient countries. Counterpart funds need to be treated with particular care where they make a substantial contribution to the budget, the money supply, or the availability of commodities, at national or regional levels.

One important provision of the new SPA and DAC principles is the idea of gradual evolution towards a situation where counterpart funds are no longer required. This will be achieved when recipient countries have efficient budgetary systems and when the procedures of policy dialogue produce policies and expenditure patterns that the donors are happy to live with. Some donors will however have to change the legislation governing counterpart funds, since they are at present required to account for counterpart funds in some detail (as, for example, with US food aid (McClelland)).

\section{THE FUTURE OF COUNTERPART FUNDS}

Counterpart funds may indeed wither away in due course, but seem likely to be with us for some time. In that case, the first priority is to implement the various sets of guidelines and narrow the large gap between best and usual practice (Maxwell in this Bulletin). In so doing, better data and better understanding of the issues in operational agencies should both result (Maxwell and Owens 1991). At the same time, the articles in this volume show that the counterpart fund mechanism can be used in innovative ways to support strategic poverty reduction and food security objectives. 
1 Counterpart funds consist of local currency generated by the sale of aid communities or foreign exchange in recipient countries, over the use of which the donor has some control.

2 The purpose of most aid which results in counterpart funds is to assist the recipient country in meeting agreed strategic objectives, through carrying out specific policies, programmes and projects. It does so by helping to meet foreign exchange and government financial requirements. The strategic objectives are likely to include poverty alleviation and food security, as well as stabilization and structural adjustment.

3 Both the provision of aid and the use, when appropriate, of counterpart funds, provide opportunities for dialogue over the size and composition of government expenditure, with due allowance for fungibility of budgets. In addition, the planning, use and monitoring of counterpart funds will require attention to policies on poverty alleviation, taxation, commodity pricing, and macroeconomic and sector policy, in order to maximize the benefit of aid and avoid the risk of dependency and disincentives. However, government policy, including policy on government expenditure, should not be developed as an adjunct to aid or counterpart funds - the reverse is the case.

4 The real resource transfers are represented by the commodity or financial aid inflows, not the counterpart funds. However, counterpart funds do constitute a mechanism for translating payments for imported goods and services into government revenue, for use on agreed programmes and projects. They may be especially appropriate if it is desirable to target or otherwise influence government expenditure.

5 The expenditure of counterpart funds will set in motion a process of expansion of demand for and production of a varied basket of commodities. For this reason, a diversified basket of aid commodities, including consumer goods, is necessary to help fill any deficit in commodity balances.

6 Dialogue oa policy issues and budget expenditure will be especially important when the total (commodity) aid/counterpart fund package supplied by all donors makes a sizeable contribution to commodity supply or the government budget, at national or regional level. If it does not, then the operating costs of counterpart funds are likely to outweigh the benefits.

7 The scope for efficient policy dialogue will be weakened if counterpart funds are allowed to accumulate; or if they are eroded by inflation, implicit subsidies or over-valued exchange rates. It will be strengthened if counterpart funds are predictable, regular, sizeable and adjusted to the inter-annual fluctuations of the recipient economy.

8 It follows that where counterpart funds are appropriate they should be:

(a) planned in advance, preferably in the context of a rolling, multi-year agreement, linked to other aid and with the possibility of 'substitution actions' on a year to year basis to ensure flexibility;

(b) disbursed in the context of an agreed policy framework, subject to regular monitoring and fully accounted in the national budget of the recipient;

(c) credited without delay to a government-controlled interest-bearing account at the full cif value, before subsidies or deductions;

(d) disbursed quickly, following an agreed plan, to the agreed programme and project spending accounts, including subsidies and domestic debt reduction where appropriate;

(e) subject to the normal budget formulation, accounting, monitoring and evaluation procedures on the financial and physical sides;

(f) managed in ways minimizing the administrative load and strengthening national planning, budgeting and reporting processes, perhaps on a multi-donor basis through the creation of a common counterpart fund account.

Source: Maxwell and Owens (1991) 


\section{REFERENCES}

Bruton, H. J. and Hill, C. B., 1991, The Development Impact of Cotnterpart Funds, USAID, Washington DC

Clément, J. A. P., 1989, 'The macroeconomic impacts of counterpart funds', Working Paper WP/89/63, African Department, International Monetary Fund, Washington, August

Club du Sahel/COBEA-ORSAY, 1991, 'Premiere analyse theorique des effects des fonds de contrepartie', Document de Travail, Club du Sahel/COBEA-ORSAY, November

Griffiths-Jones, S., 1992, 'Debt conversion techniques: an overview', mimeo, IDS, Sussex, February

Healey, J. M. and Winpenny, J. T., 1991, Overseas Development: Implementing Labour's Policies, Institute for Public Policy Research, London, December

Knop, M., 1989, 'Rapport final sur la gestion des fonds de contrepartie engendres par la vente de l'aide alimentaire de la CEE', Final Report to the European Community, Brussels, August

Maxwell, S., 1991, 'The developmental uses of counterpart funds', a report to the Commission of the European Community, partly reprinted as Discussion Paper No 289, IDS, Sussex, June

-and Singer, H. W., 1979, 'Food aid to developing countries: a survey', in World Development 17:3

-and Owens, T., 1991, 'Commodity aid and counterpart funds in Africa', Discussion Paper No 291, IDS, Sussex, June

McLeod, A. N., 1950, 'Local currency proceeds of an import surplus', International Monetary Fund Staff Papers, Vol I, IMF, Washington DC, February
Owens, T., 1991, 'Counterpart funds: an annotated bibliography', Development Bibliography No 6, IDS, Sussex, November

Roemer, M., 1989, 'The macroeconomics of counterpart funds - revisited' in World Development, 17:6

Singer, H. W., 1964, 'Use and abuse of counterpart funds', in International Development: Growth and Change, McGraw Hill, New York

-with Wood, John, and Jennings, Tony, 1987, Food Aid -The Challenge and the Opportunity, Clarendon Press, Oxford

United Nations, 1991, International Development Strategy for the Fourth United Nations Development Decade, Resolution 45/1991 adopted by the General Assembly, United Nations, New York

USAID, 1990, 'Terms of endowment: a new AID approach to institutional development', Innovative Development Approaches No 3, USAID, Washington DC, December

-1991, PL 480 Title II Guidelines, Agency for International Development, Washington DC, July

World Food Programme, 1987a, 'Monetisation of WFP food aid', WFP/CFA 24/5, Rome

$-1987 \mathrm{~b}$, 'The management of funds generated by foodassisted projects', WFP/CFA 23/5, Rome

World Bank, World Development Report, various years, Washington

-1991, Assistance Strategies to Reduce Poverty: A Policy Paper, Washington DC

World Bank and World Food Programme, 1991, Food Aid in Africa: an Agenda for the 1990s, a Joint Study by the World Bank and the World Food Programme, Washington DC and Rome, August 